\title{
Veronica Stigger
}

Como você pensa a relação entre o tempo literário e o tempo histórico?

Tendo a construir meus contos como se eles se passassem num lugar e num tempo indefinidos - embora, na maioria das vezes, eu saiba exatamente onde eles se passam (e espalho pequenas evidências disso para que o leitor aplicado possa descobri-lo...). Creio que esta disposição para certa vagueza de espaço e tempo deriva de uma tentativa de mimetizar a deslocalização e a atemporalidade características dos contos de fadas, das lendas, dos mitos - formas que venho estudando há bastante tempo, em associação com certos procedimentos da arte moderna. No entanto, operar por meio de uma eliminação - retórica, estratégica - do tempo histórico não quer dizer dar as costas para este tempo ou anular a percepção da "realidade". Pelo contrário: parece-me que esta é uma maneira crítica - e, de certo modo, mais eficaz - de dizer algo de novo sobre este tempo. Um retrato da realidade como reflexo leva ao reconhecimento, à familiaridade, o que considero, no fundo, apaziguador. Aquilo que não é reflexo (visível) conduz ao estranhamento que, quero acreditar, é mais propício à reflexão (mental).

Quais procedimentos sua obra adota diante de um mundo em que predominam a ação econômica e a espetacularização da arte?

A palavra espetáculo vem de uma raiz indo-europeia, *spek-, cujo sentido original é "olhar com atenção" Esta é, ou deveria ser, a exigência fundamental de qualquer obra literária ou artística. Se pensarmos nisso, a "espetacularização" contemporânea da arte pode ser vista, ao mesmo tempo, como uma radicalização de um aspecto originário da arte (seu oferecer-se a um olhar atento) e como uma vulgarização desse aspecto (tudo se oferece tão explicitamente, que nenhuma atenção resiste). Temos aí um impasse, com que todo artista de nosso tempo tem de se confrontar, não podendo, a meu ver, simplesmente fingir que não existe. Não há como optar, a priori, pela espetacularização ou pela não espetacularização. Já dizia Adorno: “Toda e qualquer obra de arte, pela sua simples existência, enquanto obra estranha ao que está alienado, conjura o circo; está, porém, perdida logo que com ele compete" (Adorno, Theodor W. Teoria estética. Trad. Artur Morão. São Paulo: Martins Fontes, 1982, p. 99). De minha parte, tento trabalhar criticamente com a dimensão espetacular inerente à arte do nosso tempo. E criticamente quer dizer, sobretudo, ironicamente. Não por acaso, pensei o meu livro mais recente, Gran Cabaret Demenzial, como um cabaret, como um espetáculo no qual se sucedem apresentações as mais diversas. Mas essas apresentações são às vezes bastante deceptivas do ponto de vista espetacular, na medida em que, pela ênfase no estranhamento, evito as táticas básicas da cultura do espetáculo: a identificação empática e a conclusão consoladora (e conciliadora).

\section{Como você pensa a forma literária?}

Não penso a forma literária como algo estável ou estanque, fixada em gêneros definidos, como o conto, o poema, a novela, o romance. Parece-me que a estabilidade é uma exigência antes do mercado do que da própria arte. Gosto de trabalhar com a forma, desrespeitando propositalmente os limites dos gêneros. No Gran Cabaret Demenzial, creio que isso fica mais evidente. Embora o veja como um livro de contos, seus textos assumem as mais variadas formas: poemas, anúncios publicitários, legenda fotográfica, palestra, peça teatral - e até contos propriamente ditos... O livro mesmo, como já salientei, se constitui como um espetáculo. No lugar de um sumário, tem um "programa". 
Atrai-me certa promiscuidade formal. Acho-a mais verdadeira quanto ao tempo em que vivemos.

Veronica Stigger (1973) é escritora e crítica de arte. Publicou O trágico e outras comédias (Angelus Novus, 2003/ 7 Letras, 2007), Gran Cabaret Demenzial (Cosac Naify, 2007), Os anōes (Cosac Naify, 2010) e Dora e o sol (Editora 34, 2010). 